\title{
WHAT MAKES SUMMER VACATION EXPERIENCE MEMORABLE? AN EMPIRICAL STUDY FROM CROATIA $^{4}$
}

\begin{abstract}
This paper aims to examine what kind of experience makes summer vacation memorable and consequently how it influences the overall satisfaction with a vacation experience. Based on literature review hypotheses were formulated in order to explore the multidimensionality of memorable tourist experience, the influence of different elements of memorable tourist experience on satisfaction with tourist vacation as well as the influence of satisfaction with vacation experience on the behavioural intention of tourists. For the purpose of the research, empirical research using paper and pencil questionnaire was carried out on the sample of 134 international tourists who visited traditional sun and sea destinations in Croatia in a broader Kvarner region during the summer of 2017. The research results, although of indicative nature only, point out that a memorable tourist experience consists of four different factors, namely hedonism and novelty, local culture, involvement and refreshment. Among them, local culture has the highest impact on overall satisfaction with summer vacation experience. Also, refreshment as a memorable tourist experience influences the overall vacation satisfaction. The research has also confirmed the positive relationship between the following elements: satisfaction with vacation experience on behavioural intentions that were measured through tourists' intention to return to the destination, to recommend the destination to their friends and relatives, to share experience through social media and to spend more money in tourist destinations. The strongest relationship is between tourist satisfaction with vacation experience and the intention to recommend a destination followed by intention to revisit that destination if they feel satisfied with the experience provided. Managerial implications as well as limitations and ideas for further research are given.
\end{abstract}

Keywords: memorable tourism experience, summer vacation experience, satisfaction with vacation experience, behavioural intentions

1 PhD, Associate Professor, Faculty of Tourism and Hospitality Management, University of Rijeka, Primorska 42, p.p. 97, 51410 Opatija, Croatia.E-mail: dina.loncaric@fthm.hr

2 PhD, Assistant Professor, Faculty of Economics, University of Rijeka, Ivana Filipovića 4, 51000 Rijeka, Croatia. E-mail: jasmina.dlacic@efri.hr

3 PhD, Senior Assistant, Faculty of Tourism and Hospitality Management, University of Rijeka, Primorska 42, p.p. 97, 51410 Opatija, Croatia.E-mail:marinap@fthm.hr

4 Received: 15 January 2018; Accepted: 1 April 2018 


\section{INTRODUCTION}

The goal of each journey is an experience, which, in "leisure and tourism, can be described as the subjective mental state felt by participants" (Otto and Ritchie 1996:166). The tourist experience depends on many factors (e.g. quality of accommodation, food, transport) but most of the atmosphere or experiences are created through collaboration between hosts who provide tourist experience and tourists in a particular destination. Tourists' intention to revisit a destination depends primarily on the quality of the previous experience. To enhance behavioural intention to revisit a destination, marketing managers must provide their visitors with truly memorable experiences (Kim et al. 2012; Kim and Ritchie, 2014).

Pine II and Gilmore (1998) point out that a customer experience has to be memorable. Hence, a tourist remembers a particular event, e.g. summer vacation, which will shape his attitude toward the destination if it has a positive association (Oh et al., 2007). Moreover, tourists prefer to revisit destinations of which they have positive memories of previous visits (Marschall, 2012). Various researchers proposed different dimensions of tourist experience (Pine II and Gilmore, 1998; Oh et al., 2007; Kim, 2010; Hosany and Gilbert, 2010; Tung, Ritchie, 2011; Hung et al., 2014; Kim et al., 2012; Kim, Ritchie, 2014; Kim, 2014; Triantafillidou and Petala, 2015; Prebensen et al., 2016; Ali et al., 2016) contributing to positive memories, satisfaction and behavioural intentions.

Hung et al. (2014) and Ali et al. (2016) emphasise that a number of scholars has highlighted the importance of memorable experiences in tourist activities, and yet the number of relevant empirical studies discussing this phenomenon is limited. The purpose of this paper is therefore to determine whether and to what extent summer vacation provides a memorable tourist experience and motivates tourists to return to a specific destination.

Summer vacations are crucial because of their fundamental features: good weather, relaxation, spending time with loved ones, providing emotional and physical refreshment (Kozak, 2002). Also, summer vacations "are major events in many consumers' lives which allow them to break with their everyday routines" (Decrop and Snelders, 2004:1008). Croatia is a typical example of a tourist destination with the dominance of the traditional "sun and sea" offer. This "sun and sea" tourist product in the overall Croatian tourist product has not fallen below $85 \%$ of the physical volume with a slightly smaller income share ( 75 to $80 \%$ ) (Development strategy of Croatian tourism till 2020, 2013:8). This implies that it is of crucial importance to create conditions that facilitate the realisation of positive memorable experiences connected with summer vacations and their essential attributes.

The goal is to determine which of the dimensions of the memorable tourism experience (afterwards MTE) has the greatest impact on the tourist experience and their overall satisfaction with summer vacation experience. Furthermore, the goal is to examine the relationship between satisfaction with vacation experience and behavioural intention that is manifested through intention to revisit the destination, intention to recommend the experience/destination to friends and relatives and intention to share tourist experience. 
In the following section, memorable tourist experience and behavioural intention are further conceptualised. Then, the research methodology is described, and results are reported. Last, a conclusion with discussion and managerial implications of the results are provided.

\section{LITERATURE REVIEW}

\subsection{Memorable tourism experience}

Tourism researchers have conceptualised the tourist experience and emphasised its distinctiveness from everyday life. According to researchers (Kim, 2010; Kim et al. 2012; Kim and Ritchie, 2014), tourist experience can satisfy tourist psychological needs and wants (i.e. relaxing, hedonism) which are not satisfied in their everyday routine. Events, such as vacation experiences "create flashbulb memories that are defined as exceptionally vivid and long-lasting memories of surprising events" (Myers, 2003 in Kim, 2010).

Tourists when recalling and talking about a memorable tourism experience tend to connect to their personal specific meaningful experience from the past that is remembered and selectively reconstructed (Park and Santos, 2017). According to the findings of Tung and Ritchie (2011), positive emotions and feelings associated with the experiences (e.g. happiness, excitement) are critical components of memorable tourism experience. Furthermore, Kim et al. (2012:13) have defined positive memorable tourism experience (MTE) as "a tourism experience positively remembered and recalled after the event has occurred".

There are several components of tourism experiences that strongly affect individuals and lead to memorability of an event (Kim et al., 2012): (1) the affective feelings, which are found to be better remembered; (2) the cognitive evaluations, which would enhance the recollection of a memory since one's process of retrieval involves high levels of cognitive processes and (3) the unusual, atypical and distinctive events are better remembered in comparison to typical events.

The memorable tourism experience consists of seven distinctive dimensions (Kim, 2010; Kim et al., 2012, Kim and Ritchie, 2014): hedonism, novelty, local culture, refreshment, meaningfulness, involvement and knowledge. In literature, hedonism is defined as the "pleasure of sensuous gratifications for oneself" (Schwartz, 1992 in Triantafillidou and Petala, 2015:70). When participating in tourism experiences, tourists primarily seek pleasure and enjoyment (Kim, 2014). Results of Triantafillidou and Petala's study (2015) indicated that hedonic dimension of tourist experience is significantly related to tourists' satisfaction. Furthermore, experience memorability is connected to the novelty. Tourists travel to experience something new and different, something out of the ordinary. Novelty has been related to tourists' motivation for travel (Campos et al., 2016). Tourists who are constantly travelling to new destinations are high novelty-seekers and looking for a variety of stimulations such as thrill, adventure and surprise (Tung and Ritchie, 2011). Besides, scholars have found out that experiencing local culture makes one's travel more memorable and therefore it represents an important motivational factor for travelling (Kim and Ritchie, 2014; Kim, 2014; Tung and Ritchie, 2011). Interaction with local culture and people allows tourists to create a unique experience, which will make vacation experience unforgettable. The 
most defining basic components of tourism activities are refreshment, or relaxation and renewal (Kim and Ritchie, 2014). Kozak (2002) has noted that relaxation and getting away from routine life are the first two psychological reasons for taking a vacation. Literature supports the importance of refreshment in travel experiences. For example, Arnould and Price (1993) found that extraordinary experiences such as river rafting provide personal growth and self-renewal. The results of Morgan and Xu's (2009) study indicated that summer vacation experience of relaxing on the beach is a highly memorable tourism experience. Within their travel activities, tourists search for meaningful experiences - sense of physical, emotional or spiritual fulfilment (Kim, 2014). The findings of Tung and Ritchie (2011) indicate that meaningful tourism experience lasts longer in people's memory. Involvement has been defined "as the degree of interest in an activity and the affective response associated with the interest" (Kim et al., 2015). Consequently, tourists remember an experience that is personally relevant and closely related to their interests, more than other experiences (Kim, 2014; Kim and Ritchie, 2014). Kim et al. (2015) examined the relationship between involvement and satisfaction with travel experience. The results showed that involvement positively influences satisfaction with travel experiences. Educational outcomes of experiences refer to the knowledge, where tourists acquire new information, skills and new insights through different activities. Through interaction and observing tourists increase their skills and knowledge at the destination they visit (Oh et al., 2007) which represents the educational dimension of tourism experiences. Ali et al. (2016) found that creative tourism depends heavily on tourists who are actively involved in their local surrounding, learning about their environment, and apply this knowledge to develop new skills. Based on the above analysis, the following hypothesis can be developed:

$\mathrm{H} 1$ : Memorable tourism experience is a multidimensional construct.

\section{TOURIST SATISFACTION}

In the tourism marketing literature satisfaction has been described "as an individual's cognitiveaffective state derived from a tourist experience" (del Bosque and Martin, 2008:553). Moreover, satisfaction is perceived as a result of service quality, destination image, motivation and perceived value of vacation experience (Mathis et al., 2016). "As an emotional state of mind after an experience" (Williams and Soutar, 2009:419) tourists recall their memories that contributed to their satisfaction with vacation experience. Tourism researchers tried to link tourism experiences and satisfaction, and found out that experience is an important antecedent of the overall tourist satisfaction (Triantafillidou and Petala, 2015). Moreover, recent studies have pointed out that relationship between memorable tourism experience and tourist satisfaction is well present and important. According to Oh et al. (2007) and Tung and Ritchie (2011) tourists' memories significantly affected their satisfaction and behavioural intention. Ali et al. (2016) also argued that creative tourists' memories have a positive and significant effect on tourist satisfaction. Based on previous the following hypothesis is proposed:

$\mathrm{H} 2$ : There is a positive relationship between the dimensions of memorable tourism experience and satisfaction with vacation experience. 


\section{BEHAVIOURAL INTENTIONS}

According to Reichheld (2001) focusing on developing loyalty boosts company profit. Additionally, behavioural intentions are considered to be the element that represents customer loyalty (Zeithaml et al., 1996). Behavioural intentions, moreover their positive outcomes, consist of spreading positive word of mouth, recommendations to friends, repeat patronage, buying more of the same product/ service and paying a price premium. Furthermore, Jones and Taylor (2007) develop a framework for service loyalty as they consider it as a multidimensional construct. They argue that elements of loyalty can be approached from three perspectives: behavioural (e.g. repurchase intentions), attitudinal (e.g. willingness to recommend) and cognitive (e.g. willingness to pay more). Hence, different aspects of loyalty are grouped into separate dimensions. Still, if Oliver (1999) definition is followed, loyalty is approached as re-buying or re-patronising a product or service consistently in future despite competitors' efforts to change that. This can be extended to tourism sector. So, Baker and Crompton (2000) approach revisit intentions as possibility for tourist to repeat activity and revisit a destination. Moreover, Lin (2012) argues that in tourism literature behavioural intention is widely accepted as a good proxy for future behaviour.

Tourist satisfaction is considered to influence behavioural intentions (da Costa Mendez et al., 2010). Hence, tourists that are satisfied with a destination will express an intention to return (Kozak and Rimmington, 2000; Hui et al., 2007) or to revisit it in future (Hutchinson et al., 2009; Kim et al., 2015). Also, satisfaction with destination influences intention to revisit nearby destinations in the same country (Kozak, 2001). When tourists are satisfied with a certain destination they will spread positive word of mouth (Hutchinson et al., 2009, Oliver and Swan, 1989). Nowadays social networks represent an easy and widely accepted way of sharing experiences. Hence, tourists that are satisfied with a destination are considered to be more prone to share their experiences through social networks. Also, when tourists are satisfied with a destination it is more likely that they will positively talk about it and recommend it to their friends and relatives to visit it (Bigne et al., 2001; Kozak, and Rimmington, 2000; Hui et al., 2007). Tourists that are satisfied with a destination will more likely decide to spend more money in that destination in contrast to a destination where their satisfaction is lower (Baker and Crompton, 2000).

Hence, we posit:

$\mathrm{H} 3$ : There is a positive and statistically significant relationship between satisfaction with vacation experience and behavioural intentions. Tourists that have a higher level of satisfaction with summer vacation experience are more prone to revisit the destination $(\mathrm{H} 3 \mathrm{a})$, to share their experiences via social networks $(\mathrm{H} 3 \mathrm{~b})$, to recommend the destination to friends and acquaintances $(\mathrm{H} 3 \mathrm{c})$ and spend more money in the destination $(\mathrm{H} 3 \mathrm{~d})$.

\section{RESEARCH METHODOLOGY}

The survey method was applied to accomplish the objectives of the research and to test the hypotheses. Therefore, the questionnaire was designed to gather empirical data. The measurement scales were taken from the existing literature. 
The first section measures summer holiday experience using memorable tourist experience scale developed by Kim (2010). All 24 items of the MTE scale were evaluated on 7-point Likert scales ranging from (1) "I have not experienced" to 7) "I have experienced very much".

Satisfaction with vacation experience was measured using following three statements borrowed from Prebensen et al. (2016): "I am satisfied with the decision to participate in this experience", "It was a wise choice", and "It has been a good experience". Respondents evaluated items on 5-point Likert scales ranging from (1) "strongly disagree" to (5) "strongly agree".

The same 5-point Likert scales were used to measure behavioural intentions. Revisiting a destination was explored using three statements used by Kim, Woo and Uysal, (2015): „Revisiting the destination would be worthwhile", "I will revisit the destination", and "I would like to stay more days in the destination". We adopted the scale used in work of Kim, Chua, Boo and Han (2015). To measure intention to recommend three statements were used: „I would like to recommend others to visit the destination", "I would say positive things about this summer destination to others", and "If someone is looking for good summer destination, I will suggest to him/her to patronize this destination". Three items were used to explore sharing of experience: „I have shared my tourism experience with others during this trip", "I will tell others about tourism experience I have had during this trip", and "Sharing my travel knowledge and information through social media is pleasant" (Buonincontri et al., 2017).

The questionnaire was created in English and translated into three languages: Croatian, German and Italian. The research was conducted in June and July 2017. The respondents were international tourists who visited several summer destinations in Croatia, whose tourist product is based on traditional "sun and sea" offer. Those destinations are located in broader Kvarner region. A total of 134 valid questionnaires were collected and form purposive sample for our research. Due to relatively small number of collected questionnaires this research could be approached as a pilot research offering some indicative results.

Data processing and analysis applied univariate and multivariate statistical methods in SPSS ver 23. Results of the research are presented below.

\section{FINDINGS}

In the following section research sample is analysed and hypotheses are tested.

\section{1 Sample}

The demographic structure of the sample is shown in Table 1. 
Table 1. Demographic profile of respondents $(n=134)$

\begin{tabular}{|l|c|l|c|l|c|}
\hline Gender & $\begin{array}{c}\text { Percentage of } \\
\text { respondents }\end{array}$ & Age & $\begin{array}{c}\text { Percentage of } \\
\text { respondents }\end{array}$ & \multicolumn{1}{|c|}{ Level of education } & $\begin{array}{c}\text { Percentage of } \\
\text { respondents }\end{array}$ \\
\hline Female & 44.3 & $18-25$ & 13.5 & Elementary school & 3.8 \\
\hline Male & 55.7 & $26-35$ & 25.6 & Secondary school & 19.8 \\
\hline & & $36-45$ & 23.3 & High school degree & 29.8 \\
\hline & & $46-55$ & 17.3 & University degree & 31.3 \\
\hline & & $56-65$ & 16.5 & Postgraduate-master & 15.3 \\
\hline & & 65 and more & 3.8 & & \\
\hline
\end{tabular}

Source: Research results

Out of a total of 134 respondents who completed the questionnaire, $44.3 \%$ were male and $55.7 \%$ were female. Majority of the respondents are in the age range of 26 to 35 years old (25.6\%), followed by those in the age range of 36 to 45 years old (23.3\%), then by those in the age range of 46 to 55 years old (17.2\%). Almost the same number of respondents has a university degree (31.3\%) and a high school degree (29.8\%), followed by those who have completed secondary school (19.8\%).

The study also provided some additional information on the travel behaviour of respondents. The results are illustrated in Table 2.

Table 2. Travel behaviour of respondents

\begin{tabular}{|l|c|}
\hline Description & Percentage of respondents \\
\hline Organisation of travel & 84.7 \\
\hline Individually & 15.3 \\
\hline Organized - travel agency & 1.5 \\
\hline Overnight stays & 16.7 \\
\hline 1 night & 52.3 \\
\hline $2-3$ nights & 29.5 \\
\hline 4-7 nights & \\
\hline More than 7 nights & 1.5 \\
\hline Accompanying person during travel & 36.9 \\
\hline Alone & 30.8 \\
\hline With partner & 13.1 \\
\hline With family members (with children) & 16.9 \\
\hline With family members (without children) & 0.8 \\
\hline With friends & \\
\hline With associates & 9.8 \\
\hline Type of accommodation & 11.4 \\
\hline $3^{*}$ hotel or less & 1.5 \\
\hline $4^{*}$ or 5* hotel & 5.3 \\
\hline tourist resort & 68.2 \\
\hline campsite & 3.8 \\
\hline private accommodation & \\
\hline friends/relatives & \\
\hline \multicolumn{2}{|l|}{} \\
\hline
\end{tabular}




\begin{tabular}{|l|l|}
\hline Number of visits to a destination \\
\hline First visit & 42.7 \\
\hline One visit before & 18.3 \\
\hline Two or more visits before & 38.9 \\
\hline
\end{tabular}

Note: $\mathrm{n}=134$

Source: Research results

Most of the respondents organised their travel individually (84.7\%) and stayed in a destination from 4 to 7 nights (52.3\%). In most of the cases the respondents travelled with a partner (36.9\%), family members (30.8\%) or friends (16.9\%). The type of accommodation in which the respondents stayed during the travel was mostly private accommodation (68.2\%). For most of the respondents this travel represents their first visit to a destination (42.7\%), followed by those who had visited that destination twice or more (38.9\%).

\section{HYPOTHESES TESTING}

Since the questionnaire was adopted from the present research and translated into three languages, it was necessary to examine the dimensionality and reliability of the memorable tourist experience scale before further analyses. For this purpose we used the exploratory factor analysis and reliability analysis.

Before the analysis, the proof of the suitability of conducting factor analysis was carried out with the help of the Kaiser-Meyer-Olkin test of sampling adequacy and Bartlett's test of sphericity. The Kaiser-MeyerOlkin coefficient $(0.909)$ and Bartlett's test of sphericity $\left(X_{(276)}^{2}=2399.69 ; p<0.001\right)$ showed that the correlation matrix was suitable for carrying out the factor analysis according to the recommendations of Tabachnik and Fidell (2007, p. 614). Dimensionality of the MTE scale was tested using principal component analysis with oblique rotation. Direct oblimin method was used since the goal was data reduction to a smaller number of variables assuming that factors might correlate (Field, 2009, p. 644). The criteria for the number of factors extracted and variables retained were based on eigenvalues and percentage of variance explained. Factors with eigenvalues greater than 1 and a solution with at least $60 \%$ of the total variance explained were considered as acceptable. To check the reliability of the scales, Cronbach's alpha coefficients were calculated.

The results presented in Table 3 were obtained for the MTE scale.

Table 3. Results of descriptive statistics, factor and reliability analysis for MTE scale

\begin{tabular}{|l|c|c|c|c|c|}
\hline Item & $\begin{array}{c}\text { Factor } \\
\text { loading }\end{array}$ & $\begin{array}{c}\text { Total } \\
\text { variance } \\
\text { explained } \\
\text { (\%) }\end{array}$ & $\begin{array}{c}\text { Alpha } \\
\text { coefficient }\end{array}$ & Mean & SD \\
\hline FACTOR 1 - HEDONISM AND NOVELTY & & $\mathbf{5 1 . 0 7}$ & $\mathbf{0 . 9 1 1}$ & $\mathbf{4 . 9 0}$ & $\mathbf{1 . 2 2}$ \\
\hline Thrilled about having a new experience & 0.775 & & & & \\
\hline Really enjoyed this tourism experience & 0.746 & & & & \\
\hline Experienced something new & 0.730 & & & & \\
\hline Exciting & 0.646 & & & & \\
\hline Once-in-a-lifetime experience & 0.640 & & & & \\
\hline Different from previous experiences & 0.596 & & & & \\
\hline
\end{tabular}




\begin{tabular}{|l|c|c|c|c|c|}
\hline Unique & 0.563 & & & & \\
\hline Indulged in the activities & 0.521 & & & & \\
\hline FACTOR 2 - LOCAL CULTURE & & $\mathbf{7 . 4 7}$ & $\mathbf{0 . 7 6 6}$ & $\mathbf{5 . 6 9}$ & $\mathbf{1 . 0 7}$ \\
\hline Local people in a destination were friendly & 0.819 & & & & \\
\hline Good impressions about the local people & 0.616 & & & & \\
\hline Closely experienced the local culture & 0.575 & & & & \\
\hline FACTOR 3 - INVOLVEMENT & & $\mathbf{5 . 7 1}$ & $\mathbf{0 . 9 0 1}$ & $\mathbf{4 . 9 2}$ & $\mathbf{1 . 2 8}$ \\
\hline I visited a place where I really wanted to go & 0.780 & & & & \\
\hline Knowledge & 0.741 & & & & \\
\hline $\begin{array}{l}\text { I was interested in the main activities of this tourism } \\
\text { experience }\end{array}$ & 0.724 & & & & \\
\hline I enjoyed activities which I really wanted to do & 0.626 & & & & \\
\hline New culture & 0.607 & & & & \\
\hline Learned about myself & 0.583 & & & & \\
\hline I did something important & 0.550 & & & & \\
\hline Exploratory & 0.523 & & & & \\
\hline FACTOR 4- REFRESHMENT & & $\mathbf{4 . 4 8}$ & $\mathbf{0 . 9 0 4}$ & $\mathbf{4 . 9 4}$ & $\mathbf{1 . 3 5}$ \\
\hline Revitalized & 0.825 & & & & \\
\hline Refreshing & 0.816 & & & & \\
\hline Liberating & 0.770 & & & & \\
\hline Enjoyed sense of freedom & 0.717 & & & & \\
\hline I did something meaningful & 0.462 & & & & \\
\hline
\end{tabular}

Source: Research results

In contrast to the study by Kim (2010), somewhat different factor structure was obtained. Four factors were extracted that explain $68.73 \%$ of the total variance. They are named "Hedonism and novelty", "Local culture," "Involvement" and "Refreshment". This proved the first hypothesis (H1) that memorable tourist experience is a multidimensional construct.

A multiple regression analysis was applied to examine the impact of four dimensions of memorable tourist experience on satisfaction with vacation experience. Multiple regression analyses were run using the four factors of the memorable tourist experience as independent variables and the satisfaction with vacation experience as a dependent variable. The results of the impact of the memorable tourist experience on travel satisfaction are shown in Table 4.

Table 4. Multiple regression analysis for variables predicting satisfaction with summer vacation experience

\begin{tabular}{|l|c|c|c|c|c|}
\hline Independent variables & $b$ & \multicolumn{1}{|c|}{ SE } & \multicolumn{1}{c|}{ Beta } & \multicolumn{1}{c|}{ Sig. } \\
\hline Constant & 7.423 & 0.984 & & 7.540 & 0.000 \\
\hline HEDONISM AND NOVELTY & -0.001 & 0.031 & -0.003 & -0.024 & 0.981 \\
\hline LOCAL CULTURE & 0.186 & 0.064 & 0.280 & 2.907 & 0.004 \\
\hline INVOLVEMENT & -0.008 & 0.029 & -0.038 & -0.272 & 0.786 \\
\hline REFRESHMENT & 0.095 & 0.044 & 0.306 & 2.140 & 0.034 \\
\hline
\end{tabular}




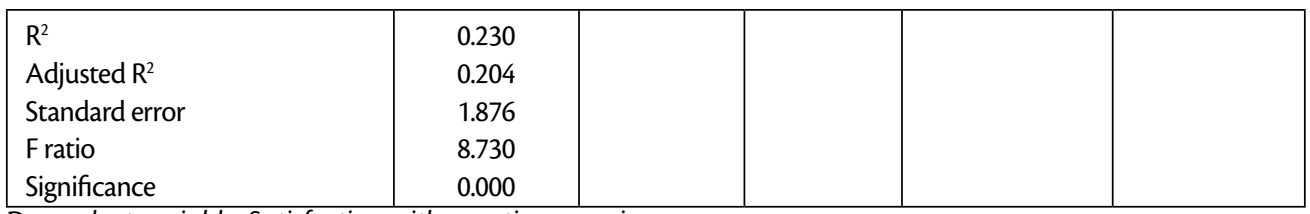

Dependent variable: Satisfaction with vacation experience

Source: Research results

Among four extracted factors, second factor "Local culture" $(\beta=0.280, p=0.004)$ and fourth factor „Refreshment" ( $\beta=0.306, p=0.034)$ significantly influences satisfaction with a vacation experience. Other two factors do not have a significant impact on satisfaction with summer vacation experience. On the basis of this evidence, we can conclude that there is a statistical significant relationship between memorable tourist experience and satisfaction with a vacation experience. So, hypothesis $\mathrm{H} 2$ is confirmed.

To explore whether there is a relationship between satisfaction with vacation experience and behavioural intentions we applied correlation analysis. Pearson correlation coefficients were calculated to explore the relationships among the research variables.

A correlation analysis among the variables "Satisfaction with vacation experience", and the variables "Intention to revisit the destination", "Intention to recommend" and "Sharing experience" the Pearsons' coefficient of correlation was applied in order to test hypothesis H3. Results are shown in the Table 5.

Table 5. Correlation coefficients

\begin{tabular}{|l|r|r|r|r|r|}
\hline & Satisfaction & Revisit & Sharing & Recommend & \multicolumn{1}{c|}{ Expenditure } \\
\hline Satisfaction & 1 & $0.487^{* *}$ & $0.342^{* *}$ & $0.517^{* *}$ & $0.272^{* *}$ \\
\hline Revisit & & 1 & $0.496^{* *}$ & $0.762^{* *}$ & $0.362^{* *}$ \\
\hline Sharing & & & 1 & $0.593^{* *}$ & $0.355^{* *}$ \\
\hline Recommend & & & & 1 & $0.353^{* *}$ \\
\hline Expenditure & & & & & 1 \\
\hline
\end{tabular}

Note: ${ }^{* *}$. Correlation is significant at the 0.01 level (2-tailed).

Source: Research results

Statistically significant correlations were established between the variables "Satisfaction with vacation experience", "Intention to revisit the destination" ( $r=0.487, p<0.001)$, "Intention to recommend" $(r=0.517, p<0.001)$, "Sharing experience" ( $r=0.342, p<0.001)$, and "Expenditure" $(r=0.272, p<0.001)$. Therefore, we can conclude that hypotheses $\mathrm{H} 3 \mathrm{a}, \mathrm{H} 3 \mathrm{~b}$ and $\mathrm{H} 3 \mathrm{c}$ and $\mathrm{H} 3 \mathrm{~d}$ are confirmed. We can therefore conclude that there is a relationship between the satisfaction with vacation experience and behavioural intentions. 


\section{DISCUSSION AND CONCLUSIONS}

Our study, although of indicative nature only, offers insights and contributes to better understanding of summer vacation experiences in a traditional "sun and sea" destination. The contribution is found in several domains. Firstly, testing memorable tourism experience scale has shown that in our setting four-factor structure emerged. Hence, the MTE scale used can be applied to measure summer vacation experience but with slightly different factor structure than proposed by Kim (2010). This can lead to a conclusion that the MTE scale has to be further tested in different settings and cultures to provide its reliability. Second, local culture is a factor with the highest average in the MTE scale. This implies that tourists in a traditional sun and sea destination are looking for something more than just enjoying and relaxing on the beach. Experiencing local culture is found to be important. This is consistent with findings of Lin (2012) who focuses on local cuisine and finds that cuisine experience drives tourists to revisit the destination.

Third, satisfaction with vacation experience is influenced and enhanced through interaction with locals and local culture as well as it is enhanced by individuals' sense of feeling refreshed and revitalised after vacation experience in a destination. Similarly, Hui et al. (2007) realised that culture is important in achieving overall satisfaction with a destination. But this was not consistent through different groups of respondents in their study. Fourth, satisfaction with vacation experience is positively related and enhances intention to revisit destination, stimulates tourists to share through social media their vacation experiences and to recommend it to friends and relatives to visit that destination. Also, if they are satisfied with vacation experience they will spend more money during that vacation. This is consistent with findings of several different studies (e.g. Hutchinson et al., 2009; Hui et al., 2007; Baker and Crompton, 2000) that reveal positive relationship between satisfaction after visiting a destination and the future behaviour of tourists.

Managerial implications are oriented towards necessity for destination management or tourist organisations to provide, besides sun and sea relaxation, additional offering in their destinations focused more on interaction with local culture and local inhabitants. This could lead to developing a specific gastro offering inspired with local ingredients and regional recipes. Furthermore, it can also be oriented towards guided tours through local villages and offering tourists the possibility to interact with local inhabitants through getting to know their customs and tradition.

Our study is a preliminary indicative study and, like many others in the field, is not without limitations. The limitations lie in the relatively the small sample size as well as in the small number of explored destinations, predominantly located in the broader Kvarner region. Furthermore, the sample is purposive. This could be expanded of in further researches that should aim at broadening the sample, forming structured sample and including a greater number of destinations from different locations along the Croatian coastline. Moreover, it could also focus on different destinations like adventure or wellness destinations, not just on the traditional sun and sea ones.

\section{ACKNOWLEDGMENT}

This paper has been financially supported by the University of Rijeka for Project ZP UNIRI 2/16. 


\section{Lončarić, J. Dlačić, M. Perišić Prodan: What Makes Summer Vacation Experience Memorable... Zbornik Veleučilišta u Rijeci, Vol. 6 (2018), No. 1, pp. 67-80}

\section{REFERENCES}

Ali, F., Ryu, K., Hussain, K. (2016) "Influence of experiences on memories, satisfaction and behavioral intentions:

A study of creative tourism", Journal of Travel \& Tourism Marketing, 33(1), p. 85-100

Arnould, E. J., Price, L. L. (1993) “River magic: Extraordinary experience and the extended service encounter”, Journal of Consumer Research, 20(1), p. 24-45

Baker, D. A. Crompton, J. L. (2000) “Quality, satisfaction and behavioral intentions”, Annals of tourism research, 27(3), p. 785-804

Bigne, J. E., Sanchez, M. I. Sanchez, J. (2001) "Tourism image, evaluation variables and after purchase behaviour: interrelationship", Tourism Management, 22(6), p. 607-616

Buonincontri, P. et al. (2017) "Managing the experience co-creation process in tourism destinations: Empirical findings from Naples", Tourism Management, 62, p. 264-277

Campos, A.C., Mendes, J., do Valle, P.O., Scott, N. (2016) "Co-creation experiences: attention and memorability", Journal of Travel \& Tourism Marketing, 33(9), p. 1309-1336

da Costa Mendes, J. et al. (2010) "The tourist experience: Exploring the relationship between tourist satisfaction and destination loyalty", Turizam: znanstveno-stručni časopis, 58(2), p. 111-126

Decrop, A., Snelders, D. (2004) “Planning the summer vacation: An adaptable process”, Annals of Tourism Research, 31(4), p. $1008-1030$

del Bosque, I. R., San Martín, H. (2008) “Tourist satisfaction a cognitive-affective model”, Annals of tourism research, 35(2), p. 551-573.

Development strategy of Croatian tourism till 2020 [Strategija razvoja turizma Republike Hrvatske do 2020. godine], NN 55/2013, https://narodne-novine.nn.hr/clanci/sluzbeni/2013_05_55_1119.html (1. 12. 2017.)

Field, A. (2009) Discovering statistics using SPSS, Third edition. London: Sage Hosany, S., Gilbert, D. (2010) "Measuring Tourists' Emotional Experiences toward Hedonic Holiday Destinations",

Journal of Travel Research, 49(4), p. 513-526

Hui, T. K., Wan, D. Ho, A. (2007) “Tourists' satisfaction, recommendation and revisiting Singapore”, Tourism Management, 28(4), p. $965-975$

Hung, W. L., Lee, Y. J., Huang, P. H. (2016) “Creative experiences, memorability and revisit intention in creative tourism”, Current Issues in Tourism,19(8), p. 763-770

Hutchinson, J., Lai, F. Wang, Y. (2009) “Understanding the relationships of quality, value, equity, satisfaction, and behavioral intentions among golf travelers", Tourism Management, 30(2), p. 298-308

Jones, T., Taylor, S. F. (2007) “The conceptual domain of service loyalty: how many dimensions?”, Journal of Services Marketing, 21(1), p. 36-51

Kim, H.C. et al. (2015) "Understanding airline travelers' perceptions of well-being: The role of cognition, emotion, and sensory experiences in airline lounges", Journal of Travel \& Tourism Marketing, 33(9), p. 1213-1234

Kim, H., Woo, E. Uysal, M. (2015) “Tourism experience and quality of life among elderly tourists”, Tourism Management, 46, p. 465-476

Kim, J. H. (2010) "Determining the Factors Affecting the Memorable Nature of Travel Experiences", Journal of Travel \& Tourism Marketing, 27(8), p. 780-796

Kim, J. H. (2014) "The antecedents of memorable tourism experiences: The development of a scale to measure the destination attributes associated with memorable experiences", Tourism Management, 44, 34-45.

Kim, J. H., Ritchie, J. B. (2014) “Cross-Cultural Validation of a Memorable Tourism Experience Scale (MTES)”, Journal of Travel Research, 53(3), p. 323-335 
Kim, J. H., Ritchie, J. R. B., McCormick, B. (2012) “Development of a Scale to Measure Memorable Tourism Experiences”, Journal of Travel Research, 51(1), p. 12-25

Kozak, M. (2001) “Repeaters' behavior at two distinct destinations", Annals of tourism research, 28(3), p. 784-807

Kozak, M. (2002) "Comparative analysis of tourist motivations by nationality and destinations", Tourism Management, 23(3), p. 221-232

Kozak, M., Rimmington, M. (2000) "Tourist satisfaction with Mallorca, Spain, as an off-season holiday destination", Journal of Travel Research, 38(3), p. 260-269

Lin, C. H. (2012) "Effects of cuisine experience, psychological well-being, and self-health perception on the revisit intention of hot springs tourists",Journal of Hospitality \& Tourism Research, 38(2), p. 243-265

Marschall, S. (2012) '"Personal memory tourism' and a wider exploration of the tourism- memory nexus", Journal of Tourism and Cultural Change, 10(4), p. 321-335

Mathis, E. F. et al. (2016) “The effect of co-creation experience on outcome variable”, Annals of Tourism Research, 57, p. $62-75$

Morgan, M., Xu, F. (2009) "Student travel experiences: Memories and dreams", Journal of Hospitality Marketing \& Management, 18(2-3), p. 216-236

Oh, H., Fiore, A. M., Jeoung, M. (2007) "Measuring experience economy concepts: Tourism applications", Journal of Travel Research, 46(2), p. 119-132

Oliver, R. L. (1999) “Whence consumer loyalty” Journal of Marketing, 63(s.i., 4), p. 33-44

Oliver, R. L., Swan, J.E. (1989) "Consumer perceptions of interpersonal equity and satisfaction in transactions: a field survey approach", The Journal of Marketing, p. 21-35

Otto, J. E., Ritchie, J. B. (1996) “The service experience in tourism”, Tourism management, 17(3), 165-174.

Park, S., Santos, C. A. (2017) “Exploring the tourist experience: A sequential approach", Journal of Travel Research, 56(1), p. 16-27

Pine II, B. J., Gilmore, J. H. (1998) “Welcome to the experience economy”, Harvard business review, 76, 97-105

Prebensen, N. K., Kim, H., Uysal, M. (2016) "Cocreation as moderator between the experience value and satisfaction relationship", Journal of Travel Research, 55(7), p. 934-945

Reichheld, F. F. (2001a). The loyalty effect: The hidden force behind growth, profits, and lasting value. Boston: Harvard Business School Press

Tabachnik B. G. and Fidell L. S. (2007) Using Multivariate Statistics, Fifth Edition, Boston, MA: Pearson Education

Triantafillidou, A., Petala, Z. (2016) "The role of sea-based adventure experiences in tourists' satisfaction and behavioral intentions", Journal of Travel \& Tourism Marketing, 33, p. 67-87

Tung, V. W. S., Ritchie, J. B. (2011) “Exploring the essence of memorable tourism experiences", Annals of tourism research, 38(4), p. 1367-1386

Williams, P., Soutar, G. N. (2009) "Value, satisfaction and behavioral intentions in an adventure tourism context", Annals of Tourism Research, 36(3), p. 413-438

Zeithaml, V. A., Berry, L. L., Parasuraman, A. (1996) “The behavioral consequences of service quality”, Journal of Marketing, $60(2)$, p. $31-46$ 


\section{ŠTO ČINI LJETNI ODMOR NEZABORAVNIM? EMPIRIJSKI DOKAZI IZ HRVATSKE ${ }^{4}$}

\section{SAŽETAK}

Surha rada je istražiti koja ursta iskustva turista najviše pridonosi nezaboravnom doživljaju ljetnog odmora i posljedično utječe na ukupno zadovoljstvo doživljajem na odmoru. Temeljem pregleda literature razvijene su i predložene hipoteze u cilju istraživanja višedimenzionalnosti nezaboravnog doživljaja turista, istraživanja utjecaja različitih elemenata nezaboravnog doživljaja turista na ukupno zadovoljstvo doživljajem na odmoru, kao i istraživanja povezanosti zadovoljstva doživljajem na odmoru i namjere ponašanja turista u budućnosti. Da bi se postigla surha istraživanja, provedeno je empirijsko istraživanje pomoću anketnog upitnika koji je proveden na uzorku od 134 inozemna turista koji su tijekom ljeta 2017. godine boravili u tradicionalnim ljetnim destinacijama u Hrvatskoj na širem području Kvarnera, čija se ponuda temelji na moru i suncu. Rezultati istraživanja iako indikativni po svojoj prirodi ukazuju da se nezaboravni doživljaj turista sastoji od četiri različita faktora, odnosno od hedonizma i želje za novotarijama, lokalne kulture, uključenosti i osjećaja osvježenosti. Među njima lokalna kultura ima najveći utjecaj na ukupno zadovoljstvo s doživljajem na odmoru. Istraživanje je također potvrdilo pozitivnu povezanost zadovoljstva s doživljajem na odmoru i namjere ponašanja turista u budućnosti. Namjere ponašanja turista u budućnosti ispitivale su se kroz namjeru povratka u destinaciju, namjeru preporuke posjete destinaciji prijateljima i rođacima, dijeljenje iskustva putem društvenih medija te namjeru da se potroši veći iznos novaca u turističkoj destinaciji. Najsnažnija veza uturđena je između zadovoljstva turista doživljajem na odmoru i namjere da se preporuči posjet destinaciji. Sljedeća po jačini je povezanost namjere da se ponovi posjet destinaciji ako su turisti zadovoljni doživljajem odmora. Također, rad sadrži i implikacije za menadžere te ograničenja i preporuke za buduća istraživanja.

Ključne riječi: nezaboravni doživljaj turista, doživljaj ljetnog odmora, ukupno zadovoljstvo s dožilljajem na odmoru, namjere ponašanja

1 Dr. sc., izvanredni profesor, Fakultet za menadžment u turizmu i ugostiteljstvu, Sveučilište u Rijeci, Primorska 42, p. p. 97, 51410 Opatija, Hrvatska.E-mail: dina.loncaric@fthm.hr

2 Dr. sc., docent, Ekonomski fakultet, Sveučilište u Rijeci, Ivana Filipovića 4, 51000 Rijeka, Hrvatska. E-mail: jasmina.dlacic@efri.hr

3 Dr. sc., viši asistent, Fakultet za menadžment u turizmu i ugostiteljstvu, Sveučilište u Rijeci, Primorska 42, p. p. 97, 51410 Opatija, Hrvatska. E-mail: marinap@fthm.hr

4 Datum primitka rada: 15. 1. 2018.; datum prihvaćanja rada: 1. 4. 2018. 